\title{
Building Within Space: Thoughts Towards an Environmental Ethics
}

Troy Paddock (Southern Connecticut State University; New Haven, Connecticut, United States)

\section{Introduction}

It is exceedingly difficult to think about our natural environment clearly. It is often challenging to get scholars to agree even on what a definition of nature or the natural environment might entail. Part of this difficulty stems from understanding exactly where human beings stand in relation to the natural environment. Does "nature" include humanity? Must the concept of "wilderness" exclude people in order for it to be authentically wild (Nash 1982)? In order to have a functional environmental ethics that can have a meaningful impact on the issue of sustainability, a clear understanding of the environment or nature is a fundamental prerequisite.

For the purposes of this essay, I am employing the term "nature" in one of its common usage forms: the totality of everything on the planet. The term nature refers to the natural world. In his The Idea of Nature, R.G. Collingwood identified three distinct ideas of nature that he called the Greek, the Renaissance, and the Modern. The Greek view considered nature to be like a living organism, closely fusing what might be called mind/spirit/soul with the material world. The Renaissance view, marked by the Scientific Revolution, perceived of nature as mechanical, operating according to natural laws that are eternal and unchanging. The modern view is a merging of the two and can be best identified in a shorthand fashion with evolution. Nature is once again reanimated with life, but it operates according to laws that provide an explanation for change (Collingwood 1960).

A first step in the process of developing a new environmental ethics is changing how we think about the environment. Instead of thinking of the environment as an object that is acted upon, it might be useful to think of the environment as a space that human beings act within. Thinking about the environment in terms of space rather than as an object puts both sustainability and ethics in a different light and opens up the possibility of drawing from different fields for fresh insights. Architecture is one such field. Architecture is fundamentally about the organization of space. This essay will look at the works of Christian Norberg Schultz and Bernard Tschumi in an effort to see what their theories about architecture offer for thinking about the environment. I will employ the Mosel River in Germany as a concrete example 
that illustrates how to think anew about environmental conservation and ethics. Finally, the essay will suggest that ideas from Aristotle and Actor Network Theory can help provide a paradigm within which we can think about nature in a way that offers an alternative framing to questions about the environment.

\section{Environment as Object vs. Environment as Space}

One reason for the difficulty surrounding our understanding of the environment is that many, at least in the West, are trapped in a nostalgic relationship with the environment. The environmental historian Donald Worster suggests that this nostalgia is, at least in part, a response to industrialization - a harkening back to a simpler time. Worster indicates that this nostalgia may be our only hope for salvation. For him, this nostalgia takes him back to a time and place when nature was more pristine and humanity treated its environment with more respect-Worster has in mind the Blue Ridge Mountains during the late 18th and early 19th century (1993). But even Worster's characterization reveals a common limitation in how people think and talk about the environment; nature is viewed as an object that is acted upon and controlled by human beings. The characterization is fundamentally anthropocentric and instrumentalist. Whether nature is reduced to an object that must be overcome or, in Worster's sense of nostalgia, protected, the underlying epistemological view is similar. This characterization of nature is most clearly illustrated in the title of a recent and deservedly well-received book on rivers, focusing on the Rhine and Oder, simply called: The Conquest of Nature: Water, Landscape and the Making of Modern Germany, by David Blackbourn. The conquest of a waterway is not a view that is limited to Prussia. In Landscape and Memory, Simon Schama offers a revealing anecdote: The first English hydraulic engineering feat was the construction of the flood defenses of Dagenham in the early eighteenth century.

To celebrate the achievement, the king's commissioners of work had, it seems, held a great whitebait dinner every spring as if somehow the appearance of the fish were a sign that God would indeed Save the Hanoverian King and his fisherman from the tides of flood and war (Schama 1995, 353).

The instrumentalist view of nature is fundamentally about the organization (and occasionally rearranging) of space by humans. Architecture may well have some insight into thinking about nature and ways to rethink the human relationship to nature. Fundamentally, architecture is about the organization of space. How we organize space reflects our understanding of reality; our understanding of space impacts how we act and has implications for how we understand conservation and how we determine ethical action. For example, as the Norwegian architect, architectural historian, and theorist 
Christian Norberg-Schulz points out, during the Middle Ages reality was understood as an ordered cosmos (Norberg-Schulz 1988, 17). Gothic architecture reinforced this view. Elements of reality were qualitative and their significance was determined by divine revelation (Panofsky 1976). Actions and ethical conduct were proscribed by divine revelation. Norberg-Schulz suggests that during the modern era humanity set itself rationally and critically opposite from the world. By situating itself opposite the world, the world becomes something outside that human beings act upon rather than act within. According to Norberg-Schulz, Functionalist Architecture was the epitome of this world view of man ordering the world. The functionalist notion of form following function was indicative of the view that human constructions occurred in a virtually empty geometric space in which human beings proscribed meaning.

In Genius loci, Norberg-Schulz suggests that human-made places relate to nature in three ways. First, human beings want to make the natural structure more precise. This helps them to visualize an "understanding of nature" (Norberg-Schulz 1979, 17). An individual builds what he or she has seen-an enclosure for delimited space, a Mal for centralized space, and a path for where nature suggests a direction. Second, built spaces can complement nature, adding to what is lacking. This leads to the third way: architecture as a way to symbolize humanity's understanding of nature. While this reading of the relationship between nature and architecture is certainly more sympathetic than a functionalist view, the notion that it symbolizes humanity's understanding of nature has some epistemological difficulties (Norberg-Schulz 1979). The position outlined is fundamentally anthropocentric. For an example, where an open field ends and a forest begins does not necessarily suggest a boundary or enclosure. Animals pass from one to another without any concern save perhaps bumping their head on a low-lying branch. Similarly the notion of complementarity posited by Norberg-Schulz assumes a lack that humans need to address; however, I would argue that the lack is not in nature, but in what people need from a particular place.

Norberg-Schulz's intellectual approach strongly suggests that he was heavily influenced by the work of Martin Heidegger. In Architecture: Meaning and Place, Norberg-Schulz writes: "Only when space becomes a system of meaningful places, does it become alive to us. ... 'Landscape' is structured in advance. It contains a system of existing ways which define our possibilities of movement" (Norberg-Schulz 1988, 24). He identifies the task of the architect as giving the system of meaningful places form such that they can receive the necessary content. In the chapter that explores the implications of Heidegger's thought on architecture, Norberg-Schulz asserts that "Being-in-the-world" implies a man-made environment. To explore this concept further, NorbergSchulz turns to Heidegger's discussion of the Greek temple in order to 
understand "Being-in-the world," or how things become what they are (see Heidegger 1971).

The Greeks called this emerging and rising in itself and in all things is called phusis. It clears and illuminates, also, that on which man bases his dwelling. We call this ground dwelling. We call this ground the earth.... Earth is that whence the arising brings back and shelters without violation. In things that arise, earth is present as a sheltering agent (Norberg-Schulz 1988, 39).

The notion of a proper relationship between a person and a physical structure, and between a physical structure and its natural environment, is not limited to homes. Norberg-Schulz's elegant excursion on the "Earth and Sky" of Jorn Utzon's Bagsvaerd Church reveals his Heideggarian bend in viewing architecture. As he starts his description of the space contained by the church, Norberg Schulz reminds the reader that a religious encounter takes places between earth and sky, as everything else does. "It means that the church should make an 'understood world manifest'” (Norberg-Schulz 1988, 227).

But contrary to Heidegger's view, and Norberg-Schulz's, this understanding that takes place between earth and sky does not occur without violation. Another architect, Bernard Tschumi has some observations that merit consideration in this problem. In Architecture and Disjunction, he writes,

Indeed, architecture constitutes the reality of experience while this reality gets in the way of the overall vision. Architecture constitutes the abstraction of absolute truth, while this very truth gets in the way of feeling. We cannot both experience and think that we experience. 'The concept of dog does not bark,' the concept of space is not in space (Tschumi 1994, 48).

Tschumi posits two premises to begin a chapter entitled "Violence of Architecture": first, "[T]here is no architecture without action, no architecture without events, no architecture without program"; and second "[B]y extension, there is no architecture without violence" $(1994,121)$. The first of these statements runs against the mainstream of architectural thought by refusing to favor space at the expense of action. The second argues that although the logic of objects and the logic of people are independent in their relations to the world, they inevitably face one another in an intense confrontation. Any relationship between a building and its users is one of violence, for any given use means the intrusion of a human body into a given space, the intrusion of one order into another. This intrusion is inherent in the idea of architecture; any reduction of architecture to its spaces at the expense of its events is as simplistic as the reduction of architecture to its facades.

Tschumi writes:

By 'violence,' I do not mean the brutality that destroys physical or emotional integrity but a metaphor for the intensity of a relationship between an individual and their surrounding 
spaces.... Architecture's violence is fundamental and unavoidable, for architecture is linked to events in the same way that the guard is linked to the prisoner, the police to the criminal, the doctor to the patient, order to chaos. This also suggests that actions qualify spaces as much as spaces qualify actions; that space and action are inseparable and that no proper interpretation of architecture, drawing or notation can refuse to consider this fact (Tschumi 1994, 121-122).

What must first be determined is whether this relation between action and space is symmetrical-two diverging interests (people vs. spaces) affecting one another in a commensurable way-or asymmetrical, a relation in which one interest, whether space or people, clearly dominates the other. If the relationship is asymmetrical, then that would suggest that symmetry is connected to ethical action, and by extension that symmetry is required for environmental conservation.

\section{Symmetrical and Asymmetrical Action in Space: The Mosel River}

What I would like to suggest is that the violence proposed by Norberg-Schulz and Heidegger is asymmetrical and that this is most clearly demonstrated in a discussion of rivers. Here an examination of bridges will help clarify the point. According to Heidegger, the bridge does more than connect the banks; it is what allows the banks of the river to emerge as banks. The river ceases to be a boundary, and the other side of the river is brought into the sphere of experience for those who built the bridge. "The bridge gathers the ground as landscape around the stream" (Heidegger 1971b 152). The bridge permits the river to continue its course but also allows mankind to go on with its necessary business. Heidegger writes, "The bridge is a location. As such a thing, it allows a space into which earth and heaven, divinities and mortals are admitted" (Heidegger 1971b, 155). Human life takes place on earth and the bridge makes that manifest. Norberg-Schulz notes that cities divided by a river use a bridge to become a connective way (Norberg-Schulz 1988).

But the connection that Norberg-Schulz notes privileges the human perspective. The connection was not there in nature; nor was it necessary. Rather, the connection was a human action designed to complete nature. The relationship is asymmetrical because a type of violence has been done to the river. It has been viewed as an obstacle to be overcome. The river is, in a sense, the enemy that must be conquered. It appears that the taming of rivers is a frequent topic of discussion by environmental historians. Whether it is Richard White's The Organic Machine, about the damming of the Columbia River, or Mark Cioc's The Rhine: An Eco-biography 1815-2000, the focus of the environmental historian tends to be on how mankind attempts to control 
nature and the consequences of those efforts. This approach reveals the fundamental relationship between human built-spaces and nature as one of violence and control. Cioc's eco-biography brilliantly traces the efforts to turn the Rhine into the perfect canal. His work reinforces the asymmetrical relationship. Each technological attempt to tame the "wild Rhine" produces the desired effect and an unanticipated side-effect that requires another technological remedy. The efforts that Cioc examines betray an instrumental and anthropocentric view of nature. Moreover, the actions inadvertently treat rivers like the empty kind of space that Heidegger refers to as zwischenraum (in-between space) in his discussion of highways (Heidegger 1977). Both the river and the road are treated as empty spaces. The river itself is unimportant except as an avenue of transportation to particular locations. Environmental historians, who tend to be receptive to the notion of human arrogance regarding nature, unconsciously share and perpetuate this perspective. The works of Blackbourn, White, and Cioc have noted the damage done by people and now recent attempts to at least halt, if they cannot restore, the damage that has been done by the last two hundred plus years. The action in this relationship with the environment remains asymmetrical, with one side doing violence, both symbolic and real, to the other.

To bring this to a more concrete level, I will turn to the example of the Mosel (Moselle) River. The largest tributary of the Rhine, the Mosel River flows some 339 miles through northeastern France, Luxembourg, and western Germany. It rises in the Vosges Mountains in France, in two headwaters uniting near St-Maurice. It flows north past Metz and is canalized from Thionville to its confluence with the Rhine at Koblenz, Germany. In France, there are a number of important coal deposits that facilitate the mining and steel industries in the Moselle valley; whereas in Germany it is the home of some of the best German wines.

A quick search of the books about the Mosel River turns up Jean Cermakian's The Moselle: River and Canal from the Roman Empire to the European Economic Community (1975) as yet another example of humanity's attempt to alter nature to fit its needs. Although literature on the Mosel is not substantial, this does not diminish the importance of the river itself. As Cermakian suggests, the river has quite a history and could provide a useful test case for a study of how to think about rivers and their relationship to human activity. The Mosel has been an important river at least since the founding of Trier in the first century BCE as a Roman outpost in Gaul for protection against the barbaric Germanic tribes. The earliest written references to the Mosel that we find are in Caesar. In his Conquest of Gaul, the final conquest of the Treveri under Labienus appears to have taken place next to a river that may well have been the Mosel. The battle took place beside a river with steep banks that was difficult to cross; historian Edith Mary Wightman posits that this description matches the Mosel (1971). By the time of 
Tacitus, the economic importance of Trier made the Mosel an important river as the Romans attempted to create a network of transportation routes on land and water between the Rhine. The fourth-century poet Ausonius has a poem entitled "Mosella," which is the longest single writing from antiquity that discusses the Mosel and offers us insight on how to think about rivers differently.

Ostensibly about a trip from Bingen to Trier, the poem is much more. In the first two parts, Ausonius tells the reader where he is going and praises the river he is about to travel. The subsequent four sections praise the natural beauty of the river and all that it has to offer, to both the human and the divine. The section on the gods is significant in that it emphasizes the connection between the natural and the divine. There are two quick points to make about what Ausonius writes. First, he offers praise to the natural beauty of the Mosel and all that it has to offer to humans and the divine as both a playground and sanctuary. The clumsy Satyr cannot grasp the water Nymph, and is left clutching yielding water. Even viewing the references to Satyrs and Nymphs as poetic license rather than theological truth, the poem still posits the view of the divine as in harmony with nature. Second, as Ausonius gets ready to embark on his trip along the river he writes:

Go now, and with Phrygian slabs lay out smooth floors spreading and expensive marble through thy fretted halls! But I, scorning what wealth and riches have bestowed, will marvel at Nature's handiwork, and not at that wherein ruin wantons, recklessly prodigal and delighting in her waste. Here firm sands spread the moist shores, and the foot resting on them leaves no recording print behind (Ausonius 1961, 229, lines 48-54).

Ausonius distinguishes between man-made wealth and the wealth of nature. The next two sections focus on that natural wealth, the vast variety of fishes that can be found in the Mosel and what, undoubtedly, is still the single identifying feature of the Mosel: its vineyards.

Ausonius describes some of the villas that he sees along the river:

This one stands high upon a mass of natural rock, this rests upon the verge of the jutting bank, this stands back and claims the river for its own, making it prisoner in an enfolding bay. Yon occupies a hill whose bulk looms high about the stream, claiming free prospect o'er tilth, o'er waste, and the rich outlook enjoys the lands about as though its own" (Ausonius 1961, 249-51, lines 320-326).

However elaborate these may sound to us, he assures the reader a few lines later: "so great is the charm of its refinement and distinction, while its pleasures breed no excess" (Ausonius 1961, 253, line 348).

The view of the Mosel described by Ausonius is in line with Collingwood's idea of the Greek view of Nature, in which there is a natural 
organic harmony connecting humanity and nature and a natural symmetry in the relationship between the two. The description of the villas reveals an effort to minimize the kind of violence that Tschumi discusses. The harmony Ausonius describes is natural, but it is not necessarily self-sustaining; it must consciously be maintained. Ausonius's references to the excess of needless wealth and the boundaries between humanity and nature speak to the necessity of the individual being mindful of actions.

Some fourteen centuries after Ausonius, George Waring Jr. describes his trip down the Mosel in The Bride of the Rhine: Two Hundred Miles in a Mosel Row Boat (1878). Identifying it as "the pearl of German rivers," Waring observes that although "Metz and Trier have been touched by the railway, which has somewhat torn the veil from over them ..., even they have held out bravely, and once beyond their gates we wander again in the charmed light of the Middle Ages" (Waring 1878, 15). On the very next page, he writes: "I have seen no country equal to the Mosel Valley for the peculiar charm that comes of antiquity made real by an appropriate human life" (Waring 1878, 16). What he might mean by this is revealed in a later chapter recounting his party's visit to Trier:

If the rain has wetted the country roads, one is awaked at dawn by the clattering of sabots on the stones, and the streets are filled in the early morning with peasant men driving wagons, drawn by cows yoked from the horns; with broad backed peasant-women carrying knapsack-like baskets heavily laden with potatoes, or with grain; and one is greeted by a variety of street sights and sounds entirely unfamiliar to the American ear (Waring 1878, 85).

Proceeding downstream from Metz, Waring notes that they go through the last lock of the canalization of the Mosel. There will be no other man-made stops to hinder the traveler the rest of the way to the Rhine. It will not be until after the Second World War that the three additional existing locks are constructed. Waring's account is idyllic to say the least. He revels in describing his meals and lodging and his interactions with the local inhabitants. He enjoys recounting various legends associated with the Mosel and offers Ausonius's poem at the end of his own book. It is fairly clear that while his book is not in verse, he envisions it as a modern complement to the work of "The Old Roman Poet" - his reference to Ausonius.

Waring's description of the Mosel valley is an interesting combination of all three of Collingwood's categories: the Greek, the Renaissance, and the Modern. His phrase "made real by an appropriate human life" harkens to a time past with people living simply and in harmony with nature. At the same time, Waring's pleasure at noting that the railroad was situated far enough away as to not disturb his afternoon, illustrates the impact of the Renaissance view of 
nature-which laid the intellectual foundation for industrialization-although he certainly does not refer to it as such.

The juxtaposition and tension between the industrial and pre-industrial is readily apparent as he runs out of river to meander down. Waring writes:

It would seem proper to put a period to this long account of a journey down the Mosel by describing Koblenz with some minuteness. But Koblenz, although an extremely old town, is at the same time, a busy modern town, and any account of it must be pitched in a key that would throw the whole story of our idling along the beautiful river, among its medieval towns, and through its outlying pastoral villages, sadly into discord. Any guidebook of the Rhine will give an account of Koblenz and its history that is well worth reading, - but to me, its chief interest will always lie in the fact that at the wharf above its Roman bridge one may take a steamer to Kochem or Trier (Waring 1877, 255).

In this closing passage it is clear that our traveler views the Mosel has being part of a different time and place than the busy modern world. Koblenz is the gateway between the Mosel and the modern world However, it is worth noting that while he went down the Mosel in a row boat, he mentions taking a steamer up the river. In spite of the fondness with which he recounts his journey and his time spent among the medieval towns and pastoral villages, Waring is also forward looking.

After regretting that he had not planned enough time for this trip, for each new twist in the Mosel between Schloss Ehrenburg and Koblenz reveals a new site that they did not have time to give due attention to, Waring writes:

There comes, also, the longing for the day when pocket photography will be cheap and easy and when we who write shall not have to contend against the cost of engraving. The old men and old women of the Mosel-and the chubby little children, and the young men and maidens are all clamoring for admission to my pages; but alas! They and their picturesque old houses must await the coming of the happy day when photography and the printing press shall be really wedded. They are betrothed now, but there are costly formalities still standing between them Waring 1877, 246-48).

The two quotations, only a few pages apart from each other, reveal a tension that is fundamental to the modern age and humanity's relation with nature. On the one hand, Waring is looking forward to the inevitable improvement in technology that will reduce the cost of image reproduction in books. On the other hand, the images that he wants to reproduce are of areas and people who have been minimally affected by the advances in industrialization and technology that would make the reproduction possible. More than a century before Worster, Waring is displaying the same sense of 
nostalgia and loss that Worster laments. A disconnection with nature is at the heart of this sense of nostalgia and loss.

\section{Asymmetry in Ethics and Environmentalism}

In The Question Concerning Technology, Heidegger argues that technology has fundamentally altered how people think, see, and live in the world. In a fashion that highlights Waring's predicament, Heidegger writes, "Everywhere we remain unfree and chained to technology, whether we passionately affirm or deny it" (Heidegger 1977, 4). The asymmetrical relationship between humanity and nature leaves mankind in control and bound to nature. The cause of this bondage is an epistemological turn which results in human beings looking at nature through a lens of modern science whose essence "entraps nature as a calculable coherence of forces" (Heidegger 1977, 21). Heidegger notes that the relationship between technology and physics is correct; but at the same time the relationship has transformed how human beings interact with nature. Heidegger writes:

Hence physics, in all its retreating from the representation turned only toward objects that has alone been standard until recently, will never be able to renounce this one thing: that nature reports itself in some way or other that is identifiable through calculation and that it remains orderable as a system of information (Heidegger 1977, 23).

The consequences of this perspective are seen in modern technology. The windmill using wind for energy does not reflect the same view of nature as mining the earth for coal or refitting a section of the Rhine for a hydroelectric plant. The actions for these three examples are extraordinarily dissimilar, but nonetheless require a certain kind of knowledge about the environment. The former requires a familiarity of weather patterns and knowing, literally, which way the wind blows. It takes an aspect of the natural environment, in this case the wind, as it is and uses it to produce energy without altering the source of the energy. The latter two examples are based on modern scientific knowledge and require a fundamental altering of the environment in order to provide energy. Once coal is mined and used, it is gone and cannot be reused. The river that powers the hydroelectric plant may remain a river, but it has been altered significantly and, as the history of the Rhine confirms, requires continual adjustments to offset the unintended consequences of human intervention. Both kinds of technological interaction are based on an understanding or knowledge of nature, but the former relationship is symmetrical and the latter two are clearly asymmetrical. Heidegger traces the origin of the term "technology" from Technikon, meaning "that which belongs to techne" (Heidegger 1977, 12). He continues with the observation that techne has always been linked to episteme and that both words represent a very broad 
sense of knowing, implying a sense of understanding and expertise (Heidegger 1977, 13).

In On the Soul, Aristotle writes that:

Knowledge of the essential nature of a substance is largely promoted by an acquaintance with its properties: For when we are able to give an account conformable to experience of all or most of the properties of a substance, we shall be in the most favorable position to say something worth saying about the essential nature of a subject; in all demonstration a definition of essence is required as a starting point, so that definitions which do not enable us to discover the incidental properties, or which fail to facilitate even a conjecture about them, must obviously, one and all, be dialectical and futile (Aristotle 1984, 402b21$403 b 2,642)$.

Knowledge becomes a social process based on consensus, and in a sense utility. From this perspective, the banks of a river do not come forth because of the bridge; they are banks and are identified as such because they are part of the properties that a river possesses. The river has a dynamic of its own that is independent of humanity. Humans gain knowledge of the river (or of nature) when they interact with it. It is a matter of action and inter-action, not of thinking or language.

In a sense, the phronimos, Aristotle's ethically wise person, borrows goods from the river to sustain herself. In this process, the person acquires a debt, which arises because of need, not due to the ephemeral. John Scott notes that:

Aristotle's practically wise dweller is not enabled by the mere material possession of her dwelling in this instrumental way. The two kinds of needs are of different orders. One need constitutes a 'there' or a place, a soul erotically and generatively open to any and all possible satisfactions, any and all goods that actually support living well. The need for the [weaving] shuttle, on the other hand is less open. The need for the shuttle is instrumental and hypothetical, not generative (Scott 2002, 142).

From Heidegger's perspective, modern technology has turned humanity's relationship with nature into the second kind of order, merely instrumental. In Heidegger's language, nature has becoming nothing more than a "standing reserve" (Heidegger 1977).

Modern environmentalists have embraced Heidegger's thinking about technology and its relationship to nature. However, many environmentalists have not escaped the epistemological trap that Heidegger had identified with modern science and technology. In "The Death of Environmentalism. Global Warming Politics in a Post-environmental World" - an essay that created a bit of stir when it was first presented in 2004-Michael Shellenberger and Ted Nordhaus argued that by focusing purely on global warming policy and 
projects environmentalists have marginalized themselves from public debate and have not been nearly as effective as they would like to be. They need to consider the broader scope of environmental problems the global community faces. By advocating policy measures that attempt to address environmental issues in a purely scientific way, Nordhaus and Shellenberger suggest that environmentalists have isolated themselves from possible political allies who, although they might not share the same passion about the issues, could provide valuable political support.

Shellenberger and Nordhaus argue further that "the environmental movement's incuriosity about the interests of potential allies depends on it never challenging the most basic assumptions about what does and does not get counted as 'environmental.' Because we define environmental problems so narrowly, environmental leaders come up with equally narrow solutions" (Shellenberger and Nordhaus 2004, 9-10.) The authors point out that many environmentalists make the common mistake of "advocat[ing] technical policy solutions as though politics didn't matter" (Shellenberger and Nordhaus 2004, 25). Shellenberger and Nordhaus point to the New Apollo Project as a step in the right direction since it integrates multiple political interests for a common good. The plan to create a workable majority for environmental issues is perhaps an improvement, but it is not enough politically or epistemologically.

Shellenberger and Nordhaus write, "Environmentalism is today more about protecting a supposed 'thing' - 'the environment' - than advancing the world view articulated by Sierra Club founder John Muir, 'When we try to pick out anything by itself, we find it hitched to everything else in the Universe'" (Shellenberger and Nordhaus 2004, 9). Shellenberger and Nordhaus suggest that thinking about "the environment" as a thing rather than as a mental category results in environmentalists doing "their work as though these are literal rather than figurative truths" (Shellenberger and Nordhaus, 200412 13). They point to a blind spot in much of the modern thinking about the environment that is fundamentally anthropocentric and instrumentalist. Nature is thought of as a thing that can be acted upon and controlled/protected rather than as part of the world that humans and non-humans live in and share.

A quick return to Ausonius might be helpful here. Ausonius's poem is ostensibly about a trip he took from Bingen to Trier. But it is much richer than it appears. The description of the water as transparent gives the impression that it holds no secrets, but that transparency soon gives way to the reflection of the vineyards on the hills. There is a boundary between the super and subaqueous realms that must not be violated. Ausonius's playful description of the failure of the Satyrs to grasp the elusive Nymphs was indicative of the proper relation between the two worlds of air and water. The description of the boys fishing on the banks reveals the violence of the transgression:

All unsuspecting, the wandering finny tribe rush upon them agape; and when-too late! - their open gullets feel the 
concealed barbs pierce deep within, they struggle and their struggles are betrayed above, when the wand bends in response to the tremulous vibrations of the quivering line (Ausonius 1961, 243 lines 250-53).

Ausonius's almost idyllic journey down the Mosel provides an insight into how to approach thinking about rivers in a new way. Ausonius's meditation is a journey, an action. And it might be in action that we find a way to think about rivers and other built or built upon spaces differently. John Scott argues that for Heidegger, language provides a place where mortals eternally search for meaning as dwellers, but at the same time language conceals this true meaning. Norberg-Schulz approvingly cites Heidegger's comment about language being the first art (Norberg-Schulz 1988). Scott suggests that Aristotle's attempt at a phenomenology of natural things that understood "presence as accommodated in a mediated and reflective way through a mechanism, not of production and use, but of acts based on debt and various kinds of possession, ... make[s] it possible not just to die well, but to live well" (Scott 2002, 126).

\section{Conclusion}

Where does "action" leave us in terms of how to think about the environment in a way that is not instrumental and overly anthropocentric? Or to rephrase the question: Is a return to a more symmetrical relationship between human beings and nature the key to creating an environmental policy and ethics that is more than glorified nostalgia? I think I have the beginnings of an answer. Part of the solution is to go from macro to micro in historical scope. Instead of viewing the problems of getting goods from Metz to Koblenz (the two navigable endpoints of the Mosel) and the process of how that was resolved, it may be more fruitful and interesting to view the interaction of the places and spaces along the way of the river. In western Germany the Mosel meanders along numerous small villages. Exploring the histories of these villages and how they interacted with the river, or managed their debt, to use Aristotle's term, is a possible way to de-instrumentalize the Mosel. A way to do this that honors the notion of action and consensus that Scott suggests that Aristotle is aiming for is to employ a sociological method known as Actor Network Theory, or ANT.

In Politics of Nature: How to Bring the Sciences into Democracy, Bruno Latour offers a harsh critique of environmentalists and of "political ecology" in a way that echoes Heidegger's critique, as well as those of Schellenberger and Nordhaus. Latour writes that "this nature becomes knowable through the intermediary of the sciences; it has been formed through networks of instruments; it is defined through the intervention of professions, disciplines, and protocols; it is distributed via databases; it is provided with arguments through learned societies" (Latour 2004, 4). Juxtaposed to this scientific 
concern is an aesthetic one that seeks to protect nature. These two concerns seem to be irreconcilable. Latour notes:

Every time we seek to mix scientific facts with aesthetic, political, economic and moral values, we find ourselves in a quandary. If we concede too much to facts, the human element in its entirety tilts into objectivity and becomes a countable and calculable thing, a bottom line in terms of energy, one species among others. If we concede too much to values, all of nature tilts into the uncertainty of myth, into poetry or romanticism; everything becomes soul and spirit. If we mix facts and values we go from bad to worse, for we are depriving ourselves of both autonomous knowledge and independent morality (Latour 2004, 4).

Latour proposes a new approach, in his words literally a new Constitution, that will include both human and nonhuman as a way to transcend the difficulty outlined above.

Latour's approach is intriguing for it opens up the possibility of (reJestablishing a symmetrical relationship between the human and nonhuman. If it is possible to change the view of nature as something calculable or as a "standing reserve," it might be possible to arrive at a conservationist ethics that follows Scott's view of Aristotle's ethics, where the individual is mindful of his or her debt to others, both human and nonhuman, and acts accordingly. Scott notes in Plato's Republic that Cephalus suggests that debt plays a key role in allowing him to be the human being that he is; the ability to repay integrates him into the social order. Recollection, Socrates's key to knowledge, is crucial for a person to remember exactly what was borrowed and what is needed to repay the debt (Scott 2002).

In terms of the environment, understanding our debt involves the realization that human interaction with the environment is an exchange where people who take from the environment (we all do) owe it a debt of sorts. In a real sense, the current situation is more dire than the one that Scott discusses in "Having a Need to Act" (2002); Scott touches upon the role of the State in Plato's Republic to place restrictions on the seemingly limitless skills of the artists and technologist whose activity make the State possible. The twenty-first century world faces a similar predicament. The skill of the artists and technologists is virtually limitless. But limitless production is not desirable because it causes damage-perhaps irreparable damage-to the environment. The solution to the problem is not the philosopher-king, but rather a functioning political system along the lines of what Latour discusses where environmentalists, scientists, and economic interests cooperate in an effort to manage the debt that human beings acquire. It is a call for a politics that allows for a sustainable economy in a sustainable environment-a relationship in which human interaction with the environment is more symmetrical and less nostalgic. 


\section{Literature}

Aristotle. 1984. "On the Soul”. In Barnes, J. (Ed.), The Complete Works of Aristotle. Vol.1. Princeton: Princeton University Press.

Ausonius. 1961. “The Moselle”. In Loeb Classical Library: Ausonius I. Trans. H. G.

E. White. Cambridge: Harvard University Press.

Blackbourn, D. 2006. The Conquest of Nature. Water, Landscape, and the Making of Modern Germany. New York: W.W. Norton.

Cermakian, J. 1975. The Moselle. River and Canal from the Roman Empire to the European Economic Community. Toronto: University of Toronto Press.

Cioc, Mark. 2001. The Rhine: An Ecobiography 1815-2000. Seattle: University of Washington Press.

Collingwood, R.G. 1960. The Idea of Nature. Oxford: Oxford University Press.

Heidegger, M. 1971a. "The Origin of the Work of Art". In Poetry, Language,

Thought. Trans. A. Hofstadter. New York: Harper and Row Publishers.

Heidegger, M. 1971b. "Building, Dwelling, Thinking”. In Poetry, Language,

Thought. Trans. A. Hofstadter. New York: Harper and Row Publishers.

Heidegger, Martin. 1977. "The Question Concerning Technology”. In The

Question Concerning Technology and Other Essays. Trans. W. Lovitt. New York: Harper Torchbooks.

Latour, B. 2004. Politics and Nature. How to Bring the Sciences into Democracy. Cambridge, MA: Harvard University Press.

Nash, R. 1982. Wilderness and the American Mind. $3^{\text {rd }}$ edition. New Haven: Yale University Press.

Norberg-Schulz, Ch. 1979. Genius Loci: Towards a Phenomenology of Architecture. New York: Rizzoli.

—. 1988. Architecture: Meaning and Place. Selected Essays. New York: Rizzoli.

Panofsky, E. 1976. Gothic Architecture and Scholasticism. New York: New American Library.

Schama, S. 1995. Landscape and Memory. New York: Alfred A. Knopf, Inc.

Scott, J. 2002. "Having a Need to Act." In Backhaus, G. \& Murungi, J. (Eds.),

Transformations of Urban and Suburban Landscapes. Perspectives from

Philosophy, Geography, and Architecture. Lahnam, MD: Lexington Books: 125-152.

Shellenberger, M. \& Nordhaus, T. 2004. "The Death of Environmentalism. Global Warming Politics in a Post-environmental World". Available from: http://heartland.org/sites/all/modules/custom/heartland_migration/fi les/pdfs/16188.pdf [Last accessed March 28, 2013].

Tschumi, B. 1994. Architecture and Disjunction. Cambridge, MA: MIT Press.

Waring, G. 1878. The Bride of the Rhine: Two Hundred miles in a Mosel Row Boat. Boston: J.R. Osgood and Company.

Wightman, E. M. 1971. Roman Trier and the Treveri. Westport, CT: Praeger. Worster, D. 1993. The Wealth of Nature. Environmental History and the Ecological Imagination. New York: Oxford University Press. 
Troy Paddock (Southern Connecticut State University)

\title{
Building within space: Thoughts towards an Environmental Ethics
}

\begin{abstract}
The need for constructing an environmental ethics that keeps sustainability in mind is the result of a collision of the realization that the natural environment is neither limitless nor impervious to actions with a view of nature that has been fundamentally instrumentalist and anthropocentric. This paper will borrow from architectural theory in an effort to do two things: First, it will point to some of the limitations of an anthropocentric view of nature and how it impacts efforts to influence environmental policy; second, it will suggest that ideas from Aristotle and Actor Network Theory can help to provide a paradigm within which we can think about nature in a way that offers an alternative framing of questions about the environment.
\end{abstract}

Key words: Environmental ethics, conservation, architecture, action in space, Mosel River, Actor Network Theory, instrumentalism, nature

Ethics in Progress (ISSN 2084-9257). Vol. 5 (2014). No. 1. pp. 80-95.

doi:10.14746/eip.2014.1.5 